\title{
APPLICATION OF VALUE ENGINEERING IN BUILDING CONSTRUCTION
}

\author{
A. Surya Theja Reddy ${ }^{1}$ and Satyanarayana Polisetty ${ }^{2}$
}

\begin{abstract}
The current economic conditions have entailed the use of rational method and techniques and research and application of new techniques by utilizing advancements in technology in the field of production as well as in every field. Excess cost control requires to be maintained throughout the project life of building beginning from the initial stages of design. Scrutinizing the project well and considering all possible alternatives particularly in design stage are important for achieving optimum cost. The Value Engineering is an intensive, interdisciplinary problem solving activity that focuses on improving the value of the functions that are required to accomplish the goal, or objective of any product, process, service, or organization. Value Engineering is not essentially cost cutting, the main aim of value engineering is to increase the value but not to reduce cost. Each and every individual activity of conventional construction is taken and the best alternative materials are being searched. PRIMAVERA software is used in order to find the major elements based on Pareto principle.
\end{abstract}

Keywords - Value, Cost, Function, Time.

\section{INTRODUCTION}

Value engineering (VE) is a systematic method to improve the "value" of goods or products and services by using an examination of function. During the World War II, General Electric Company (GE) faced the problem of scarcity of critical materials to fulfill the demand of the war equipment. To overcome that problem, GE had to use substitute materials for those in shortage. Many of the substitutes were less expensive and better in performance. In 1947, Lawrence D. Miles, a staff engineer for GE developed a number of ideas and techniques to select alternative materials that could be used internationally. In 1954, the U.S Navy Bureau of Ships used the Value Analysis process to cost improvement during design. They called it "Value Engineering". Value engineering is also referred to as "value management" or "value methodology" (VM), and "value analysis" (VA).

Value, as defined, is the ratio of function to cost. Value can therefore be increased by either improving the function or reducing the cost. The owner's promises must also be given prior importance because those promises are key in attracting the customers. Reasons for poor value can be that, lack of information, decisions based on wrong beliefs, habitual thinking and

\footnotetext{
${ }^{1}$ Department of Civil Engineering Anurag Group of Institutions, Hyderabad, Telangana, India

${ }^{2}$ Department of Civil Engineering Anurag Group of Institutions, Hyderabad, Telangana, India
} 
reluctance to seek advice, shortage of time, changing technology, old specifications and poor human relations.

$$
\text { Value }=\text { function/overall cost }
$$

\section{VALUE ENGINEERING METHODOLOGY}

Value engineering is often done by systematically following a multi-stage job plan. The value methodology is a systematic process that follows the Job Plan. The Job Plan consists of some phases.

The recommended VE methodology (Job Plan) used by the VE team during the Workshop has five distinct phases. Briefly, these phases are:

\section{A. Information Phase -}

In the information phase, all the pertinent aspects of the project were studied and the whole information regarding the project design, background, constraints, equipment used, time taken and projected costs of each and every element are clearly collected. The information phase also includes preparation of the special tabular formats and check lists abiding to the rules of value engineering.

\section{B. Analysis Phase-}

In the analysis phase, the data collected is being analyzed clearly. The software used for the analysis of data is PRIMAVERA. All the individual elements are taken into consideration and the main activities which consume more cost are shortlisted and also the total budget for the project is generated in the form of report from PRIMAVERA.

\section{C. $\quad$ Creative Phase-}

In the creative phase, the alternative ideas for accomplishing the function of a system are made. The major work that is done in this phase is to fix the alternative materials which must be substituted with the existing materials in the conventional construction. The ideas developed in this phase should be such that the quality must not be affected. The ideas developed during the creative phase are to be evaluated and developed so that they can be recommended and implemented.

\section{Evaluation Phase -}

In the evaluation phase, the ideas generated during the Creative Phase are screened and evaluated by the team. The ideas showing the greatest potential for cost savings and project improvement are selected for further study. The alternative materials suggested in place of conventional materials are also processed in PRIMAVERA.

\section{E. Report/Presentation Phase-}

In the Report Phase, the alternatives which are evaluated are to be implemented and a Report is being generated from PRIMAVERA showing differences in cost for each and every activity. The variation of cost is also being presented in this phase.

\section{DATA ANALYSIS}

The data collection is done by following the philosophies of information phase. Aim of the data collection is to know the problem well. Data gathered from interviewing and collecting project related materials from owner, contractor and designer concerned with the project undertaken. 
Case study of residential building has taken to study value engineering application. For this a report is generated from PRIMAVERA, for this all the data regarding costs, relationships, resources are to be given. After getting the data about cost, next step is to apply Pareto Law 20/80. Pareto Law states that only around $20 \%$ of the functions constitute around $80 \%$ of the cost. These functions $(20 \%)$ are the subject of value engineering. Weight for each criterion is assigned to reflect relative importance based on the project attributes that has been clearly verified and defined.

Table -1 Detailed Cost of Existing Structure

\begin{tabular}{|c|c|c|c|c|}
\hline $\begin{array}{l}\text { Activity } \\
\text { ID }\end{array}$ & Activity Name & Start & Finish & $\begin{array}{ll}\text { Budgeted } & \text { Total } \\
\text { Cost } & \end{array}$ \\
\hline A1000 & SOP & 01-Aug-14 & 21-Nov-14 & Rs0.00 \\
\hline A1020 & Soil Testing & 01-Aug-14 & 05-Aug-14 & Rs8,000.00 \\
\hline A1030 & Architect Plan & 01-Aug-14 & 03-Aug-14 & Rs4,800.00 \\
\hline A1040 & Estimations & 06-Aug-14 & 08-Aug-14 & Rs1,600.00 \\
\hline A1080 & Clearing the Site & 26-Aug-14 & 26-Aug-14 & Rs102,000.00 \\
\hline A1090 & Pit Excavation & 27-Aug-14 & 19-Sep-14 & Rs338,000.00 \\
\hline A1110 & Shuttering for Footings & 21-Sep-14 & 01-Oct-14 & Rs79,000.00 \\
\hline A1120 & Concreting of Footings & 03-Oct-14 & 05-Nov-14 & Rs199,000.00 \\
\hline A1130 & $\begin{array}{l}\text { Shuttering for Columns } \\
\text { and Beams }\end{array}$ & 24-Nov-14 & 02-Dec-14 & Rs406,400.00 \\
\hline A1140 & $\begin{array}{l}\text { Concreting of Columns } \\
\text { and Beams }\end{array}$ & 03-Dec-14 & 26-Dec-14 & Rs395,250.00 \\
\hline A1150 & Stair Case & 27-Dec-14 & 12-Jan-15 & Rs220,850.00 \\
\hline A1160 & $\begin{array}{l}\text { Shuttering of Slab and } \\
\text { Laying Electrical Pipes }\end{array}$ & 13-Jan-15 & 20-Jan-15 & Rs3,347,200.00 \\
\hline A1170 & Concreting the Slab & 21-Jan-15 & 28-Jan-15 & Rs478,827.27 \\
\hline A1180 & $\begin{array}{l}\text { Construction of Brick } \\
\text { Walls }\end{array}$ & 30-Jan-15 & 20-Apr-15 & Rs5,400,000.00 \\
\hline A1190 & Plastering of Walls & 21-Apr-15 & 25-May-15 & Rs3,151,000.00 \\
\hline A1210 & Lift1 & 24-Apr-15 & 27-May-15 & Rs900,000.00 \\
\hline A1215 & Lift2 & 24-Apr-15 & 27-May-15 & Rs900,000.00 \\
\hline A1220 & False Ceiling & $\begin{array}{l}26-\text { May- } \\
15\end{array}$ & 17-Jul-15 & Rs1,350,000.01 \\
\hline A1230 & Flooring & 18-Jul-15 & 13-Sep-15 & Rs8,669,227.00 \\
\hline A1240 & $\begin{array}{l}\text { Laying Tiles in Kitchen } \\
\text { and Bathroom }\end{array}$ & 18-Jul-15 & 21-Aug-15 & Rs1,497,960.00 \\
\hline A1250 & $\begin{array}{l}\text { Flooring in Corridor and } \\
\text { Stair Case }\end{array}$ & 18-Jul-15 & 09-Aug-15 & Rs719,200.00 \\
\hline A1255 & $\begin{array}{l}\text { Flooring in Parking and } \\
\text { Cellar }\end{array}$ & 10-Aug-15 & 01-Sep-15 & Rs1,334,000.00 \\
\hline A1280 & $\begin{array}{l}\text { Wiring and DB } \\
\text { Installations }\end{array}$ & 22-Aug-15 & 04-Dec-15 & Rs3,375,000.00 \\
\hline A1310 & $\begin{array}{l}\text { Running Main Water } \\
\text { Pipeline from Tank }\end{array}$ & 05-Dec-15 & 19-Mar-16 & Rs4,050,000.00 \\
\hline A1320 & $\begin{array}{l}\text { Installation of Water } \\
\text { Tank }\end{array}$ & 05-Dec-15 & 08-Jan-16 & Rs $100,000.00$ \\
\hline A1350 & Fixing Door Frame & 24-Apr-16 & 08-Jun-16 & Rs2,835,000.00 \\
\hline
\end{tabular}




\begin{tabular}{|l|l|l|l|l|} 
A1360 & Fixing Door Shutter & 09-Jun-16 & 13-Jul-16 & Rs5,850,000.00 \\
\hline A1370 & Fixing Windows & 09-Jun-16 & 06-Aug-16 & Rs3,060,000.00 \\
\hline A1380 & Texture & 07-Aug-16 & 17-Aug-16 & Rs59,400.00 \\
\hline A1390 & Putty & 18-Aug-16 & 31-Aug-16 & Rs793,920.00 \\
\hline A1400 & Weather Shield & 01-Sep-16 & 12-Sep-16 & Rs660,870.00 \\
\hline A1410 & Lappum & 13-Sep-16 & 05-Oct-16 & Rs2,170,000.00 \\
\hline A1420 & Plastic Emulsion & 06-Oct-16 & 29-Oct-16 & Rs1,240,000.00 \\
\hline A1430 & Wood Enamil & 30-Oct-16 & 09-Nov-16 & Rs344,000.00 \\
\hline A1440 & Door Polish & 10-Nov-16 & 21-Nov-16 & Rs150,594.00 \\
\hline A1450 & EOP & & 21-Nov-16 & Rs0.00 \\
\hline Total & & 01-Aug-14 & 21-Nov-16 & Rs5,44,50,398.57 \\
\hline
\end{tabular}

Table-1 shows the cost of each and every element and also the duration. It was noticed that the first 7 items (out of 17) forms $67 \%$ of the total cost. This means $35 \%$ of the functions contribute $67 \%$ of the cost which is much close to Pareto Law. The area of value engineering analysis and study will be controlled by the first six functions that are listed in following table.

Table -2 List of Activities consuming more cost

\begin{tabular}{|c|l|l|}
\hline $\begin{array}{c}\text { Sr. } \\
\text { No }\end{array}$ & \multicolumn{1}{|c|}{ Work done } & Cost(Lakhs) \\
\hline 1 & Flooring & \multicolumn{2}{c|}{87} \\
2 & Doors & 70 \\
3 & Brick Wall & 54 \\
4 & Plumbing & 41.5 \\
5 & Shuttering & 38.5 \\
6 & Kitchen, corridor & 36 \\
7 & Electricity & 33 \\
8 & Plastering & 31.5 \\
& & \\
\hline
\end{tabular}

Table-2 shows the activities in descending order which are consuming more cost. These activities can also be named as major activities. So according to Pareto Law if maximum savings are to be obtained then the alternative materials are applied to these elements which are consuming more cost.

\section{RESULTS AND CONCLUSIONS}

The following alternative materials are being opted in place of the conventional materials. These materials are opted by considering many factors. Following are the alternative materials which are being replaced by the new alternative materials:

Table-3 Alternative Materials opted

\begin{tabular}{|c|c|l|}
\hline $\begin{array}{c}\text { Sr. } \\
\text { No }\end{array}$ & $\begin{array}{l}\text { Conventional } \\
\text { Materials }\end{array}$ & $\begin{array}{l}\text { Alternative } \\
\text { Materials }\end{array}$ \\
\hline
\end{tabular}




\begin{tabular}{|l|l|l|l|}
\hline \multicolumn{1}{|c|}{} & Clay Bricks & \multicolumn{1}{c|}{ AAC Blocks } \\
$\mathbf{2}$ & Vitrified Tiles & Marble Flooring \\
$\mathbf{3}$ & Internal Teak doors & Teak Veneer Doors \\
$\mathbf{4}$ & Cement Plastering & Gypsum Plastering \\
$\mathbf{5}$ & Marble Flooring on & Flamed Granite \\
$\mathbf{6}$ & Staircase & Robo Sand \\
& & River Sand & \\
\hline
\end{tabular}

which are being

all the activities

replaced with alternative materials. Clay bricks are replaced with AAC Blocks, Vitrified Tile flooring is replaced with Marble Flooring, Internal Teak doors are replaced with Teak Veneer doors, Cement Plastering is replaced with Gypsum Plastering, Marble flooring on staircase is replaced with Flamed Granite and River Sand is replaced with Robo Sand.

Following are the results obtained by substituting the above mentioned materials with the conventional construction:

1. By substituting these alternative materials, time of the project is reduced from 753 days to 723days

2. By substituting these alternative materials, cost of project is reduced from INR5,44,50,398 to INR4,78, 17,971

3. Total time saved in the project by substituting the alternative materials is 30Days

4. Total cost saved in the project by substituting the alternative materials is INR 66Lakhs

5. $12 \%$ of difference is obtained in case of cost

6. $6 \%$ of difference is obtained in case of duration

From the following results it is clear that without affecting the quality, cost of the construction can be reduced. Following things can be concluded from the results obtained:

1. Cheaper alternative materials are available in the market which satisfies the functions and requirements of the work.

2. Reducing the cost of construction is only possible when new materials are being invited and accepted in the Construction

3. Quality is maintained at desired level because there is no question to reduce cost at the expense of quality.

4. People thinking must change to accept the change in construction materials, ultimately leading to cut down the increasing construction costs without compromising in quality leading to increase in the construction value.

\section{REFERENCES}

[1] Urmila A.M., "Value Engineering for cost reduction for sustainability in construction projects", Innovation in Engineering Science and Technology, pp. 95-97, 2015.

[2] Kavoos Amirkhani, "Effect of Value Engineering in construction and project management", Journal of Fisheries and hydrobiology, vol. 10(9), pp. 351-354, 2015.

[3] Abeer Khalid Mansour and M. Abueusef, "Value Engineering in Developing Countries" International conference Data Mining, Civil and Mechanical Engineering, pp. 101-104, 2015.

[4] A. Shekari and S. Fallahian, "A New approach to linking Value Engineering and Lean Methodology ", International conference on Production research, Iran, 2007.

[5] Amrutha Chogule, A.K. Gupta and S. Patil, "Application of Value Engineering Technique to A Residential Building-Case Study", IJIRAE, Vol. 1, Issue 12, 2014.

[6] C.M. Annappa and K.S. Panitrao, "Application of Value Engineering For Cost Reduction of Household furniture Product”,IJIRSET, Vol. 3, Issue 10, 2014. 
[7] S. Atabay and N. Galipogullari, "Application of Value Engineering in Construction Projects", Journal of Traffic and Transportation Engineering, Vol. 1, pp. 39-48, 2013.

[8] V. Bharathi and R. Paranthaman, "Applicaion of Value Engineering in Building Construction”, Research Pape on Innovation, Vol. 4, Issue 4, pp. 135-138, 2014.

[9] A.J. Chavan, "Value Engineering in Construction Industry", Application of Innovation in Engineering and Management, Vol. 2, Issue 12, pp. 18-26, Dec. 2013.

[10] N. Tom, V, Gowrisankar, "Value Egineering in Residential House Construction", International Journal of Civil Engineering and Technlogy, Vol. 6, Issue 6, pp. 46-52, June 2015. 